\title{
Fixation kinetics of chelated and non-chelated zinc in semi-arid alkaline soils: application to zinc management
}

\author{
Theophilus K. Udeigwe ${ }^{1}$, Madeleine Eichmann ${ }^{1,2}$, and Matthew C. Menkiti ${ }^{3}$ \\ ${ }^{1}$ Department of Plant and Soil Science, Texas Tech University, Lubbock, Texas 79409, USA \\ ${ }^{2}$ Albrecht Daniel Thaer-Institut für Agrar- und Gartenbauwissenschaften, Humboldt University to Berlin, \\ Unter den Linden 6, 10099 Berlin, Germany \\ ${ }^{3}$ Department of Chemical Engineering, Nnamdi Azikiwe University, Awka, Nigeria \\ Correspondence to: Theophilus K. Udeigwe (theo.udeigwe@ttu.edu)
}

Received: 9 March 2016 - Published in Solid Earth Discuss.: 17 March 2016

Revised: 20 May 2016 - Accepted: 20 May 2016 - Published: 11 July 2016

\begin{abstract}
This study was designed to examine the fixation pattern and kinetics of zinc (Zn) in chelated (ethylenediaminetetraacetic acid, EDTA) and non-chelated mixed micronutrient systems of semi-arid alkaline soils from the Southern High Plains, USA. Soils were characterized for a suite of chemical and physical properties and data obtained from extraction experiments fitted to various kinetic models. About $30 \%$ more plant-available $\mathrm{Zn}$ was fixed in the non-chelated system within the first 14 days with only about $18 \%$ difference observed between the two systems by day 90, suggesting that the effectiveness of the chelated compounds tended to decrease over time. The strengths of the relationships of change in available $\mathrm{Zn}$ with respect to other micronutrients (copper, iron, and manganese) were higher and more significant in the non-chelated system (average $R^{2}$ of 0.83 ), compared to the chelated (average $R^{2}$ of 0.42 ). Fixation of plant-available $\mathrm{Zn}$ was best described by the powerfunction model $\left(R^{2}=0.94, \mathrm{SE}=0.076\right)$ in the non-chelated system, and was poorly described by all the models examined in the chelated system. Reaction rate constants and relationships generated from this study can serve as important tools for micronutrient management and for future micronutrient modeling studies on these soils and other semi-arid regions of the world.
\end{abstract}

\section{Introduction}

The soil, a subject of interdisciplinary study (Brevik et al., 2015), has numerous ecological functions, among which is the storage and cycling of plant-needed nutrients (Smith et al., 2015). Micronutrient fixation, a process that leads to the reduction of plant-available portion of micronutrients, through the interactions with other soil constituents, limits crop productivity in most parts of the world (WHO, 2000). Plant-available portion of micronutrient is generally controlled by a number of factors such as soil organic matter $(\mathrm{OM})$, clay, calcium carbonate $\left(\mathrm{CaCO}_{3}\right)$, and iron $(\mathrm{Fe})$ oxide contents, as well as $\mathrm{pH}$, aeration status, and interaction with other micronutrients (Dimkpa et al., 2013; Bindraban et al., 2015). Reduction in the availability of micronutrient could be more pronounced in calcareous or alkaline soils due to their inherently high pH (Alloway, 2008; Havlin et al., 2013), which often results in decreased solubility of most metals, leading to increased fixation of most micronutrients such as copper $(\mathrm{Cu}), \mathrm{Fe}$, manganese $(\mathrm{Mn})$, and zinc $(\mathrm{Zn})$ in soil systems (Sparks, 2003). For Zn, apart from high $\mathrm{pH}$, free $\mathrm{CaCO}_{3}$, low OM, and texture could also influence the plantavailable portion (Fageria et al., 2002; Alloway, 2008, 2009). Climatic and/or environmental conditions such as flooding and temperature variation (cool or wet season) could also affect $\mathrm{Zn}$ availability to plants (Slaton et al., 2005; Alloway, 2008, 2009; Havlin et al., 2013).

Given the ease of fixation in soil, micronutrients such as $\mathrm{Zn}$ are often recommended to be applied in the forms of organic or synthetic chelates to enhance their availability to plants. The chemistry and effectiveness of chelated micronutrient compounds have also been previously documented under certain soil conditions and types (Sekhon, 2003; Luo et al., 2005; Chiu et al., 2005; Lucena et al., 2008). However, 
due to the heterogeneous nature of soils, it could be misleading to apply findings from one soil type and region to another, thus the need for soil- and site-specific studies.

As with other arid to semi-arid regions of the world, the Southern High Plains (SHP) of the USA is currently facing numerous environmental challenges such as drought, soil salinization, and wind erosion that limit agricultural productivity (Mehta et al., 2000; Stout, 2001; Allen et al., 2005). This region is typified by semi-arid climatic conditions with characteristically alkaline soil types. Thus, the characteristically high $\mathrm{pH}$ soils and climatic conditions of this region favor micronutrient deficiency. Recent field observations have also confirmed cases of limited crop productivity resulting from low level of micronutrients, particularly $\mathrm{Zn}$ in some important agricultural soils in Texas High Plains. In spite of the agronomic significance of the soils of this region, there is still little information on the chemistry of micronutrients in the semi-arid alkaline soils of this region (Udeigwe et al., 2016). Examining the fixation kinetics of micronutrients in these soils is vital for understanding micronutrient dynamics for further development of nutrient management tools for long-term agricultural and environmental sustainability. Kinetic parameters obtained from such efforts can be used for comparisons among micronutrients as well as among soil types. A more systematic approach to study micronutrients in soil systems will encompass examining their chemistry in a mixed system of a number of other micronutrients. Simple relationships developed from such examinations could be used for future predictive purposes.

A major limitation to previous studies (Manouchehri et al., 2006; Reyhanitabar and Gilkes, 2010; Abbas and Salem, 2011) on micronutrient fixation was that the experimental conditions (e.g. sample size, reaction times, experimental duration) limit the application of findings to field settings. An extensive literature search on these semi-arid soils indicates that limited resources are available to address the following: (i) how much of applied plant-available $\mathrm{Zn}$ will be present at a specific time, (ii) the reaction rates and mechanism of $\mathrm{Zn}$ fixation, (iii) how these compare to those of other micronutrients, and (iv) how they vary among chelated and non-chelated micronutrient compounds. The objective of this study was to examine the fixation pattern and kinetics of plant-available $\mathrm{Zn}$ in chelated (ethylenediaminetetraacetic acid, EDTA) and non-chelated mixed systems of selected agriculturally important soils of the SHP, USA. The experimental conditions of this study will facilitate the easier application of findings to field settings. Findings are intended to enhance the understanding of $\mathrm{Zn}$ chemistry and management in the semi-arid regions. This study is a part of a broad project on elucidating micronutrient fate in semi-arid alkaline soils. The first part of the project, which was focused on $\mathrm{Cu}$, has been published (Udeigwe, et al., 2016) and will be referenced appropriately in this study.

\section{Materials and methods}

\subsection{Site and soil sampling description}

Soil samples of interest were collected from three different crop production sites in western Texas. These soils were identified using the Web Soil Survey of the Natural Resources Conservation Services (NRCS). Surface $(0-15 \mathrm{~cm})$ and subsurface $(15-30 \mathrm{~cm})$ soil samples were collected from three important soil series in the SHP. The soil series include the Amarillo (A), Pullman (P), and Mansker (M), and their descriptions are presented in Table 1 . The selected depths are the typical ones examined in most soil fertility and nutrient management studies (Havlin et al., 2013). Soil samples were randomly collected from approximately $12-15$ spots at each representative site, using a digging spade marked at 0 15 and $15-30 \mathrm{~cm}$ depths. Samples from the same depth at each site were combined to get a composite sample of about $10 \mathrm{~kg}$. Samplings were sometimes restricted to a defined area of approximately 5-7 ha to avoid crossing into a different soil series.

\subsection{Soil property characterization}

From each original (untreated) soil sample, a subsample of approximately $2 \mathrm{~kg}$ was ground, passed through a $2 \mathrm{~mm}$ sieve, and stored in plastic bags at a room temperature of approximately $23^{\circ} \mathrm{C}$. The samples were then analyzed for a suite of chemical and physical properties. Soil $\mathrm{pH}_{1: 2}$ and $\mathrm{EC}_{1: 2}$ were determined on a $1: 2$ soil-water ratio following the procedure described by Sparks et al. (1996). Soil OM content was determined using the loss-on-ignition method (Nelson and Sommers, 1996). Calcium carbonate content was determined using the tensimeter method $4 \mathrm{E}$ and 4E1 of the United State Department of Agriculture NRCS-Soil Survey Investigation Report (Soil Survey Staff, 2014). Particle size determination was conducted using the modified hydrometer method (Gee and Bauder, 1986). Estimation of plant-available micronutrients $(\mathrm{Cu}, \mathrm{Fe}, \mathrm{Mn}$, and $\mathrm{Zn}$ ) was conducted using diethylenetriaminepentaacetic acid (DTPA) extraction following the procedure by Lindsay and Norvell (1978). Soil-test P determination was conducted using the Mehlich 3 procedure (Mehlich, 1984). Total elemental content was determined following USEPA Method 3050B using the DigiPREP Digestion System (DigiPREP MS, SCP Science, Québec, Canada). Measurement of elements in all extracts was conducted using the inductively coupled plasma-optical emission spectroscopy (ICP-OES) (iCAP 7400, Thermo Scientific, Waltham, MA).

\subsection{Soil sample preparation and treatment application}

Soil sample from each depth was thoroughly mixed and a representative portion taken to fill a $4 \mathrm{~L}$ plastic pot. Each pot was planted with sorghum (Sorghum bicolor) and grown in the greenhouse with no nutrients added for about 35 
Table 1. Soil classification and identification of the studied semi-arid alkaline soils of the Southern High Plains, USA.

\begin{tabular}{|c|c|c|c|}
\hline Soil series & $\begin{array}{l}\text { Sample } \\
\text { ID }\end{array}$ & $\begin{array}{l}\text { Depth } \\
(\mathrm{cm})\end{array}$ & Sampling location \\
\hline $\begin{array}{l}\text { Amarillo: fine-loamy, mixed, superactive, } \\
\text { thermic Aridic Paleustalfs }\end{array}$ & $\begin{array}{l}A_{a} \\
A_{b}\end{array}$ & $\begin{array}{l}0-15 \\
15-30\end{array}$ & $33.6058^{\circ} \mathrm{N}, 101.9073^{\circ} \mathrm{W}$ \\
\hline $\begin{array}{l}\text { Mansker: coarse-loamy, carbonatic, } \\
\text { thermic Calcidic Paleustolls }\end{array}$ & $\begin{array}{l}M_{a} \\
M_{b}\end{array}$ & $\begin{array}{l}0-15 \\
15-30\end{array}$ & $34.1261^{\circ} \mathrm{N}, 101.5899^{\circ} \mathrm{W}$ \\
\hline $\begin{array}{l}\text { Pullman: fine, mixed, superactive, } \\
\text { thermic Torrertic Paleustolls }\end{array}$ & $\begin{array}{l}P_{a} \\
P_{b}\end{array}$ & $\begin{array}{l}0-15 \\
15-30\end{array}$ & $34.05901^{\circ} \mathrm{N}, 101.4773^{\circ} \mathrm{W}$ \\
\hline
\end{tabular}

Udeigwe et al. (2016)

days, an optional practice primarily aimed at further depleting the original micronutrient nutrient level of the soils prior to micronutrient treatment application. After this practice, soil samples were crushed, air dried, ground, mixed, and passed through a $2 \mathrm{~mm}$ sieve. From each soil sample, two subsets of $250 \mathrm{~g}$ samples were weighed. One set was treated with a mixture of non-chelated micronutrients and the other with a mixture of chelated micronutrients. This was accomplished by using $80 \mathrm{~mL}$ solution of each fertilizer compound mixture prepared to deliver $5 \mathrm{mg}$ of each micronutrient $(\mathrm{Cu}, \mathrm{Mn}, \mathrm{Zn}$, and $\mathrm{Fe})$ to $1 \mathrm{~kg}$ of each soil. The nonchelated micronutrient compounds used were $\mathrm{CuSO}_{4} \cdot 5 \mathrm{H}_{2} \mathrm{O}$, $\mathrm{MnSO}_{4} \cdot \mathrm{H}_{2} \mathrm{O}, \mathrm{ZnSO}_{4} \cdot \mathrm{H}_{2} \mathrm{O}$, and $\mathrm{FeSO}_{4} \cdot 7 \mathrm{H}_{2} \mathrm{O}$, while the chelated compounds were Cu-EDTA, Mn-EDTA, Zn-EDTA, and Fe-EDTA. Twelve soil-fertilizer treatments were obtained from six soil samples (three soil series by two depths) and two sets of micronutrient amendments (non-chelated mixture and chelated mixture) and each replicated twice for a total of 24 experimental samples. These experimental samples were left in an open space in the laboratory under room temperature of approximately $23^{\circ} \mathrm{C}$. Subsamples were taken from each experimental sample at 2, 5, 7, 14, 21, 28, 35, 49, 63, 77, and 90 days after treatment and analyzed for plant-available micronutrients using DTPA extraction technique (Lindsay and Norvell, 1978). Following each subsampling event, the remaining soil samples were wetted with water to approximately field capacity. The soils were wetted after each subsampling event within the first 7 days. However, after the first 7 days, sampling was conducted at 7-14-day intervals; thus, the soil samples were wetted every 7 days. The periodic wetting and drying provide a medium that will facilitate soil chemical reactions.

\subsection{Extraction procedure}

Preparation of the DTPA extractant and the extraction procedure used followed the method described by Lindsay and Norvell (1978). The DTPA extraction technique is the most commonly and broadly used approach for estimating plantavailable micronutrient cations such as $\mathrm{Fe}, \mathrm{Mn}, \mathrm{Cu}$, and $\mathrm{Zn}$ (Liang and Karamanos, 1993). In brief, $20 \mathrm{~mL}$ of DTPA ex- tracting solution was added to $10 \mathrm{~g}$ of air-dried soil sample in a $50 \mathrm{~mL}$ plastic tube. All tubes were shaken on a reciprocal shaker for $2 \mathrm{~h}$ at approximately $25^{\circ} \mathrm{C}$ and 180 oscillations per min. Following shaking, the suspensions were centrifuged for $10 \mathrm{~min}$ at $4000 \mathrm{rpm}$ and the resulting solutions filtered using Whatman 2 filter papers into $16 \mathrm{~mm}$ borosilicate glass tubes. All extractions were conducted in duplicate. All filtrates were analyzed for $\mathrm{Fe}, \mathrm{Cu}, \mathrm{Zn}$, and $\mathrm{Mn}$ using inductively coupled plasma-optical emission spectroscopy (ICP-OES) (iCAP 7400, Thermo Scientific, Waltham, MA) following USEPA Method 200.7 (USEPA-ICP Users Group, 1982). The calibration of the ICP-OES instrument was performed using calibration standards and routinely checked using a set of second source standards from a different manufacturer. As part of the quality control/quality assurance measures, check samples were inserted after every 20-25 samples and also the relative percentage difference (RPD) between duplicates was examined and $10 \%$ set as the acceptance criterion.

\subsection{Statistical analyses}

Statistical analyses were performed using the Statistical Analysis Software (SAS 9.4, SAS Institute, Cary, NC). Differences among means, where applicable, were examined using PROC GLM and mean comparison conducted using Fisher's least significance difference (LSD) at $\alpha$ level of 0.05 . The PROC REG procedure was used to conduct single linear regression analyses used in examining changes in available $\mathrm{Zn}$ with respect to other micronutrients in each system (chelated and non-chelated). The data obtained from the kinetic experiment were fitted to selected kinetic models (Table 4) to derive the needed parameters using the PROC NLIN procedure. 


\section{Results and discussion}

\subsection{Soil properties}

Selected chemical ( $\mathrm{pH}, \mathrm{EC}, \mathrm{OM}$, and $\mathrm{CaCO}_{3}$ ) and physical (textural class) properties of the soils and the variation within depth are previously summarized by Udeigwe et al. (2016). The estimated total elemental $(\mathrm{Ca}, \mathrm{Cu}, \mathrm{Fe}, \mathrm{K}, \mathrm{Mg}, \mathrm{Mn}, \mathrm{P}$, and $\mathrm{Zn}$ ) content of the soils as previously reported by Udeigwe et al. (2016) is within the typical levels found in agricultural soils (Adriano, 2001; Kabata-Pendias, 2010; Czarnecki and Düring, 2015). Likewise, the estimated plant-available nutrients of the studied soils are also previously reported by Udeigwe et al. (2016). In general, the properties of these soils are typical of those of semi-arid climates (Chesworth, 2008; Udeigwe et al., 2015).

\subsection{Short- and long-term zinc fixation pattern}

Percent estimates of fixed plant-available $\mathrm{Zn}$ determined after the first 14 days (designated as short term), and 90 days (long term) are presented in Table 2. Individual soils and depths were examined; however, findings reveal no justifiable differences among the soils worth discussing. Thus, the findings are summarized as averages of all soils within a given depth and for both depths. The percent amount fixed was approximated using the differences between days 2 and 14, and days 2 and 90 for the 14 days and 90 days examinations. Comparison was made between the chelated and non-chelated micronutrient treatments. Average values from the three soil series examined revealed that within the nonchelated system, approximately 31.3 and $41.3 \%$ of the added $\mathrm{Zn}$ was fixed in the $0-15 \mathrm{~cm}$ and $15-30 \mathrm{~cm}$ depths, respectively, after the first 14 days. When compared to the chelated system, these numbers were drastically reduced to 5.1 and $6.8 \%$ in the $0-15$ and $15-30 \mathrm{~cm}$ depths, respectively. After the first 14 days, the averages for both depths were 36.3 and $6.0 \%$ for non-chelated and chelated systems, respectively. The findings clearly indicate that chelating with EDTA reduced the amount of plant-available $\mathrm{Zn}$ fixed by soil constituents (Lopez-Valdivia et al., 2002; Chiu et al., 2005; Alvarez and Gonzalez, 2006). This observed difference between the chelated and non-chelated partly supports the high fixation of $\mathrm{Zn}$ encountered in most alkaline soil, particularly when applied non-chelated and why $\mathrm{Zn}$ is often the most deficient micronutrient in most alkaline soils (Alloway, 2008).

The amount of $\mathrm{Zn}$ fixed by the end of the experimental period of 90 days (long-term fixation) was also examined. About 51.1 and $61.4 \%$ of available $\mathrm{Zn}$ was fixed after 90 days in the non-chelated system within the $0-15$ and 15$30 \mathrm{~cm}$ depths, respectively. These numbers when compared to the chelated system were 30.7 and $45.1 \%$ for the $0-15$ and $15-30 \mathrm{~cm}$ depths, respectively. Average fixation for both depths in these semi-arid soils after 90 days was $56.2 \%$ for non-chelated system and $37.9 \%$ for chelated system, a differ-
Table 2. Average \% (with standard deviation) plant-available $\mathrm{Zn}$ fixed after 14 and 90 days in the non-chelated and chelated systems of the semi-arid alkaline soils of the Southern High Plains, USA.

\begin{tabular}{llll}
\hline \multirow{2}{*}{ Zn system } & Depth & \multicolumn{2}{c}{ \% fixed after } \\
\cline { 2 - 4 } & $\mathrm{cm}$ & 14 days & 90 days \\
\hline Non-chelated & $0-15(n=3)$ & $31.3(3.0) \mathrm{a}$ & $51.1(9.2) \mathrm{a}$ \\
& $15-30(n=3)$ & $41.3(11.5) \mathrm{a}$ & $61.4(4.4) \mathrm{a}$ \\
\cline { 2 - 4 } & All $(n=6)$ & $36.3(4.3) \mathrm{A}$ & $56.2(5.9) \mathrm{A}$ \\
\hline Chelated & $0-15(n=3)$ & $5.1(2.1) \mathrm{a}$ & $30.7(10.9) \mathrm{a}$ \\
& $15-30(n=3)$ & $6.8(2.5) \mathrm{a}$ & $45.1(14.1) \mathrm{a}$ \\
\cline { 2 - 4 } & All $(n=6)$ & $6.0(2.3) \mathrm{B}$ & $37.9(7.2) \mathrm{A}$ \\
\hline
\end{tabular}

Mean values within a column in a given $\mathrm{Zn}$ system with the same lowercase letter and mean values within a column between the $\mathrm{Zn}$ systems with the same uppercase letter are not statistically different (Fisher's LSD $\alpha=0.05$ ).

ence of approximately $18 \%$ compared to the $30 \%$ observed in the short-term fixation (14 days). The narrower differences in $\mathrm{Zn}$ fixation observed on the long term could be attributed to the half-life of the chelating agent, EDTA. A half-life of 39 to 59 days for EDTA in doses of 0.8 to $1.6 \mathrm{mmol}$ in a heavy metal phytoextraction study was estimated by Meers et al. (2005), suggesting that the effectiveness of EDTA on micronutrient mobilization will decrease over time, causing more micronutrient to be fixed by other soil constituents. This can also be partly attributed to the dissolution of calcite in these alkaline soils, which has been shown to consume EDTA, thus reducing its effectiveness (Papassiopi et al., 1999). Although not significant, the slightly higher fixation of $\mathrm{Zn}$ observed in the subsurface soil could be partly attributed to higher clay content. Clay interaction with metal cations such as $\mathrm{Zn}$, which could reduce the amount of plantextractable Zn, has been widely documented (Sparks, 2003; Eze et al., 2010; Udeigwe et al., 2015).

\subsection{Changes in available zinc with respect to other micronutrients}

Changes in the concentration of plant-available $\mathrm{Zn}$ over the experimental period of 90 days were compared to those of other micronutrients in both the chelated and non-chelated systems (Table 3). The relationships were examined among individual soil and depth; however, there was no remarkable differences among soils worth discussing. Thus, the findings are summarized as averages for the soils at each depth and for both depths combined within each $\mathrm{Zn}$ system (chelated and non-chelated). The strengths of the relationships and gradients of change between $\mathrm{Zn}$ and each of the other micronutrient elements $(\mathrm{Cu}, \mathrm{Fe}$, and $\mathrm{Mn})$ were examined using regression analyses. Within each depth, the amount of available $\mathrm{Zn}$ positively changes with each of the other micronutrients, although to a varying degree within the chelated and non-chelated micronutrient systems. Overall, the strengths 

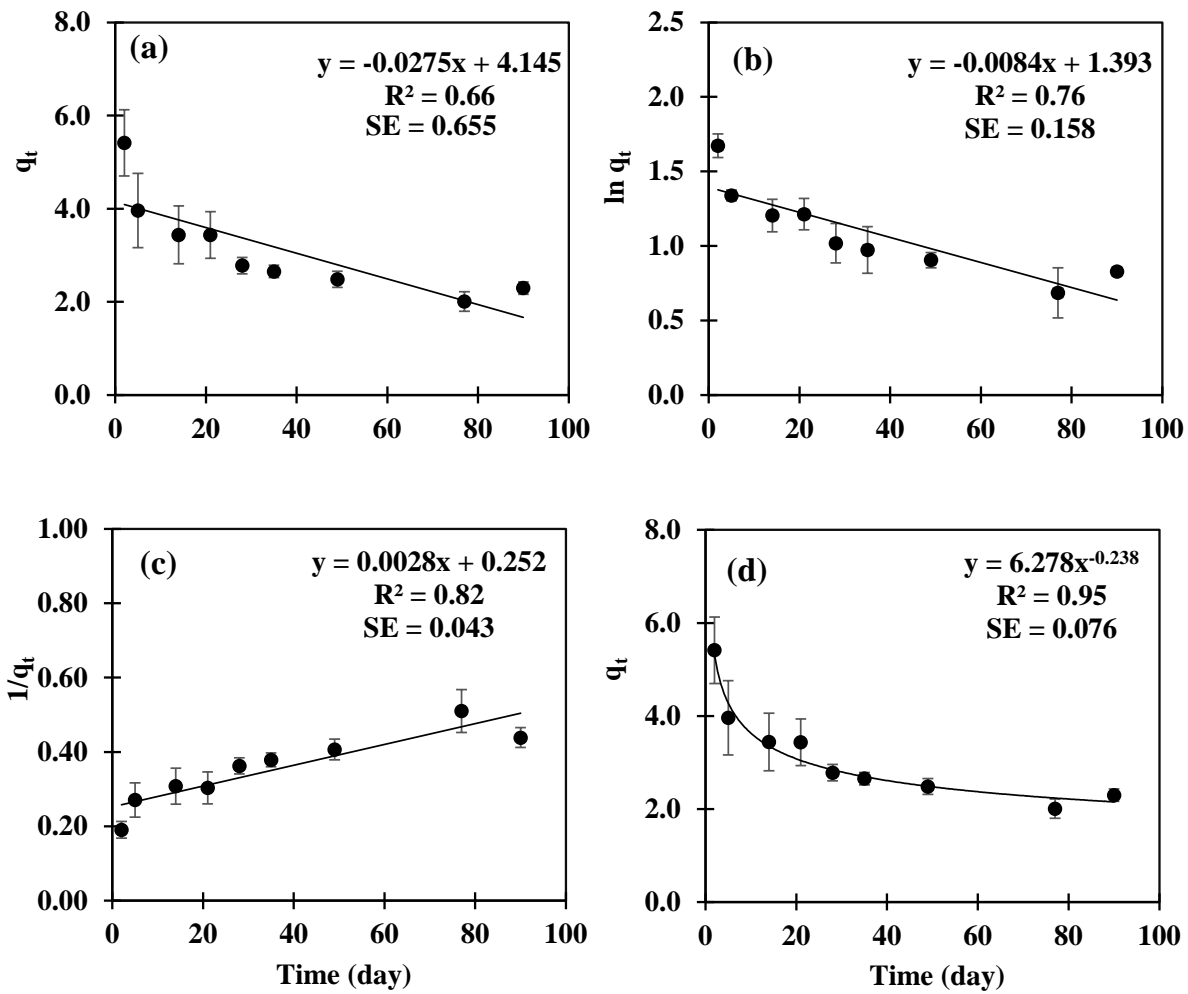

Figure 1. Diethylenetriaminepentaacetic acid (DTPA)-extractable Zn over the long term (90 days) in the non-chelated system fitted to (a) zero-order, (b) first-order, (c) second-order, and (d) power-function models ( $q_{t}$ is the amount remaining at time $t\left(\mathrm{mg} \mathrm{kg}^{-1}\right)$; error bars are for standard errors computed from six data points).

of the relationships were higher in the non-chelated systems (average $R^{2}$ of 0.83 ) compared to the chelated (average $R^{2}$ of 0.42 ), suggesting less linearity in changes in $\mathrm{Zn}$ concentration to those of the other micronutrients in the chelated system. The slopes were also generally higher in the nonchelated systems for each of the relationships examined. Within each depth in the non-chelated system, the change in available $\mathrm{Zn}$ with respect to change in $\mathrm{Cu}(\mathrm{Zn}-\mathrm{Cu})$ was higher than those of $\mathrm{Zn}-\mathrm{Fe}$ and $\mathrm{Zn}-\mathrm{Mn}$, as evidenced from the slopes of the equations. Similar relationships were also evidenced in the non-chelated system, although to a lesser strength and some were not significant (Table 3). When both depths were combined for each element, within the nonchelated system, the slopes were $0.90(\mathrm{Zn}-\mathrm{Cu}), 0.37(\mathrm{Zn}-$ $\mathrm{Fe})$, and $0.29(\mathrm{Zn}-\mathrm{Mn})$, suggesting that available $\mathrm{Cu}$ and $\mathrm{Zn}$ would tend to change at about the same magnitude in these soils as evidenced from the slope and the highly significant $R^{2}$ (Table 3). Within the non-chelated system, the findings suggest that a $1 \mathrm{mg} \mathrm{kg}^{-1}$ change in the concentration of available $\mathrm{Cu}, \mathrm{Fe}$, and $\mathrm{Mn}$, will be associated with $0.90,0.37$, and $0.29 \mathrm{mg} \mathrm{kg}^{-1}$ change in available $\mathrm{Zn}$ respectively, in these semi-arid alkaline soils of the SHP. The strong association of $\mathrm{Zn}$ and $\mathrm{Cu}$ fixation evidenced here could be attributed to the fact that these are the two most-limiting micronutrients in these soils with estimated plant-available averages of 0.38 and $0.81 \mathrm{~m} \mathrm{~kg}^{-1}$, respectively. These relationships provide an estimation of how $\mathrm{Zn}$ changes with the other micronutrients in both the chelated and non-chelated systems in this semi-arid alkaline soils. Such information is currently not available for soils of this region and as such few comparisons could be made between the findings here and existing literature.

\subsection{Kinetics of zinc fixation}

Fixation kinetics of chelated and non-chelated $\mathrm{Zn}$ in these soils were further examined by fitting the data obtained from kinetic experiments to various kinetic models. A number of kinetic models (Table 4) were examined, based on the experimental conditions of this study and evidence gathered from previous related studies (Dang et al., 1994; Reyhanitabar and Gilkes, 2010). The criteria used for evaluating best fit among the models were coefficient of determination $\left(R^{2}\right)$ and standard error (SE) (Dang et al., 1994; Reyhanitabar and Gilkes, 2010). Fixation kinetics were studied within soils and depths; however, the individual examination of soils did not show justifiable reasons to focus the discussion on the comparison among them. Thus, for further examinations, average data points for all three soils were used. 

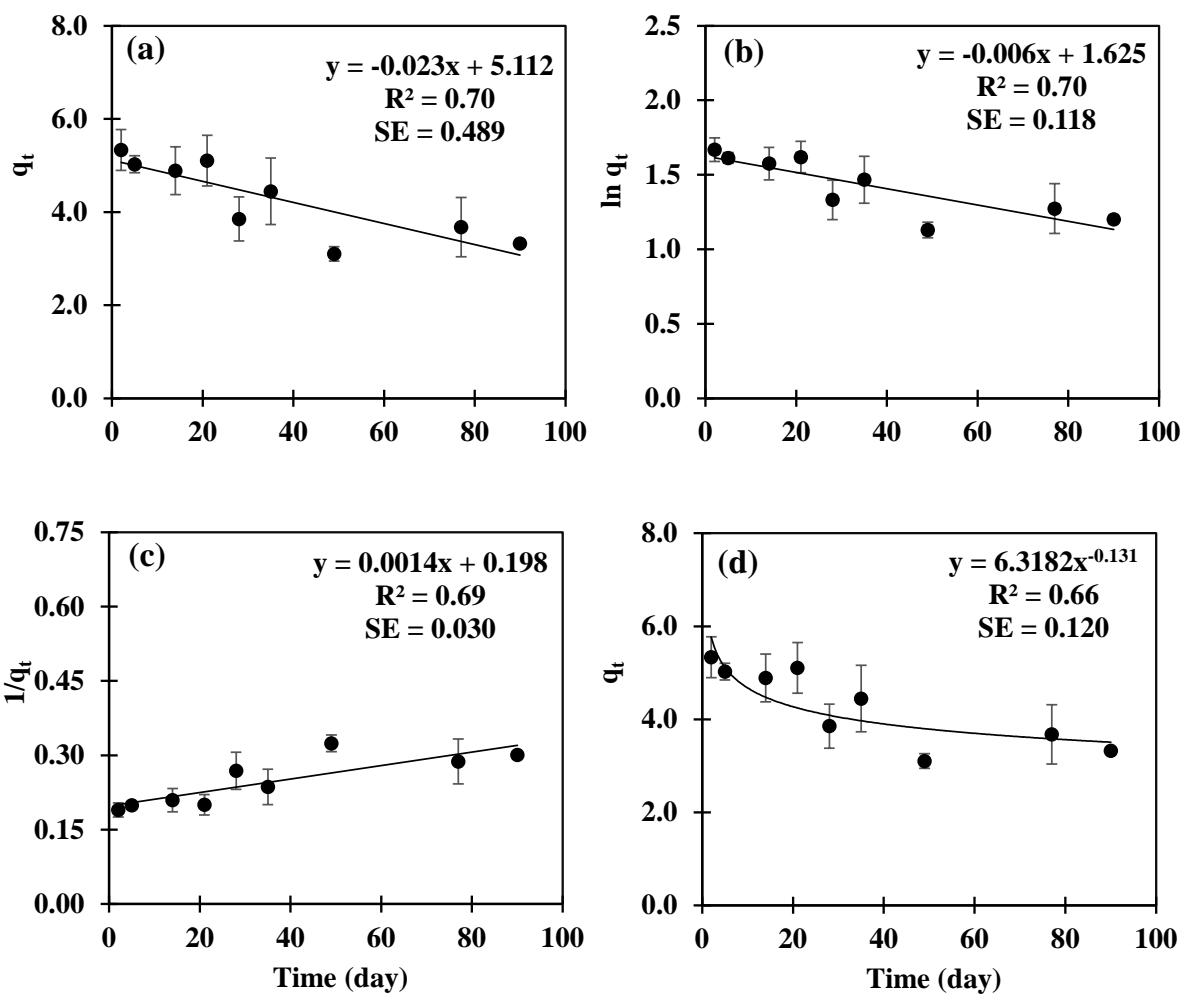

Figure 2. Diethylenetriaminepentaacetic acid (DTPA)-extractable Zn over the long term (90 days) in the chelated system fitted to (a) zeroorder, (b) first-order, (c) second-order, and (d) power-function models $\left(q_{t}\right.$ is the amount remaining at time $t\left(\mathrm{mg} \mathrm{kg}^{-1}\right)$; $\mathrm{error}^{\mathrm{bars}}$ are for standard errors computed from six data points).

Table 3. Regression equation and coefficient of determination $\left(R^{2}\right)$ of changes in available $\mathrm{Zn}$ with respect to other micronutrient elements $(\mathrm{Cu}, \mathrm{Fe}$, and $\mathrm{Zn})$ in the non-chelated and chelated systems of the studied semi-arid alkaline soils of the Southern High Plains, USA $(n=9)$.

\begin{tabular}{|c|c|c|c|c|c|c|}
\hline & \multicolumn{2}{|l|}{$\mathrm{Cu}$} & \multicolumn{2}{|l|}{$\mathrm{Fe}$} & \multicolumn{2}{|l|}{$\mathrm{Mn}$} \\
\hline & Equation & $R^{2}$ & Equation & $R^{2}$ & Equation & $R^{2}$ \\
\hline & \multicolumn{6}{|c|}{ Non-chelated } \\
\hline $0-15 \mathrm{~cm}$ & $\mathrm{Zn}=1.00 \mathrm{Cu}-0.53$ & $0.92^{* * *}$ & $\mathrm{Zn}=0.35 \mathrm{Fe}-072$ & $0.86^{* * *}$ & $\mathrm{Zn}=0.25 \mathrm{Mn}+1.46$ & $0.68^{* *}$ \\
\hline $15-30 \mathrm{~cm}$ & $\mathrm{Zn}=0.82 \mathrm{Cu}-0.60$ & $0.94^{* * *}$ & $\mathrm{Zn}=0.38 \mathrm{Fe}-0.75$ & $0.82^{* * *}$ & $\mathrm{Zn}=0.33 \mathrm{Mn}+0.21$ & $0.73^{* *}$ \\
\hline \multirow[t]{2}{*}{ All } & $\mathrm{Zn}=0.90 \mathrm{Cu}-0.54$ & $0.93^{* * *}$ & $\mathrm{Zn}=0.37 \mathrm{Fe}-0.74$ & $0.88^{* * *}$ & $\mathrm{Zn}=0.29 \mathrm{Mn}+0.84$ & $0.75^{* *}$ \\
\hline & \multicolumn{6}{|c|}{ Chelated } \\
\hline $0-15 \mathrm{~cm}$ & $\mathrm{Zn}=0.89 \mathrm{Cu}+0.27$ & $0.77^{* *}$ & $\mathrm{Zn}=0.20 \mathrm{Cu}+1.86$ & $0.46^{*}$ & $\mathrm{Zn}=0.13 \mathrm{Mn}+3.39$ & 0.31 \\
\hline $15-30 \mathrm{~cm}$ & $\mathrm{Zn}=0.66 \mathrm{Cu}+0.74$ & $0.42^{*}$ & $\mathrm{Zn}=0.15 \mathrm{Cu}+2.60$ & 0.24 & $\mathrm{Zn}=0.18 \mathrm{Mn}+2.70$ & 0.20 \\
\hline All & $\mathrm{Zn}=0.73 \mathrm{Cu}+0.73$ & $0.65^{*}$ & $\mathrm{Zn}=0.18 \mathrm{Cu}+2.24$ & $0.47^{*}$ & $\mathrm{Zn}=0.14 \mathrm{Mn}+13.14$ & 0.30 \\
\hline
\end{tabular}

* Significant at $\alpha=0.05{ }^{* *}$ significant at $\alpha=0.01 ;{ }^{* * *}$ significant at $\alpha=0.001$.

The data from $\mathrm{Zn}$ kinetic experiments were fitted to the zero-order, first-order, second-order, and power-function models and findings summarized in Table 5. In all the models, $q_{t}$ represents the amount of DTPA-extractable (plantavailable) $\mathrm{Zn}$ in $\mathrm{mg} \mathrm{kg}^{-1}$ remaining at time $t$, in days. Discussions will be concentrated on models derived using data points from both depths averaged across soils because there was no difference of interest between the $0-15$ and $15-30 \mathrm{~cm}$ depths that was worth focusing the discussion on. Employing more data points will also enhance the statistical reliability of the evaluation. In the non-chelated system, fixation of available $\mathrm{Zn}$ was poorly described by the zero-, first-, and secondorder models $\left(R^{2}: 0.66\right.$ to 0.82$)$ but better described by the power-function model $\left(R^{2}=0.95, \mathrm{SE}=0.076\right)($ Fig. 1$)$. This better fit to the power-function model suggests that the fixation of plant-available $\mathrm{Zn}$ in this mixed system of non- 
Table 4. Kinetic models used in the examination of chelated and non-chelated $\mathrm{Zn}$ fixation in the studied semi-arid alkaline soils of the Southern High Plains, USA.

\begin{tabular}{lll}
\hline Kinetic model & Equation & Parameter \\
\hline Zero order & $q_{t}=q_{0}-k_{0} t$ & $k_{0}$, zero-order rate constant $\left(\mathrm{mg} \mathrm{kg}^{-1} \mathrm{~d}^{-1}\right)$ \\
First order & $\ln q_{t}=\ln q_{0}-k_{1} t$ & $k_{1}$, first-order rate constant $\left(\mathrm{d}^{-1}\right)$ \\
Second order & $1 / q_{t}=1 / q_{0}+k_{2} t$ & $k_{2}$, second-order rate constant $\left(\left(\mathrm{mg} \mathrm{kg}^{-1}\right)^{-1} \mathrm{~d}^{-1}\right)$ \\
Power function & $q_{t}=a t^{b}$ & $a$, initial reaction magnitude constant $\left(\left(\mathrm{mg} \mathrm{kg}^{-1}\left(\mathrm{~d}^{-1}\right)^{\mathrm{b}}\right)\right)$ \\
& & and $b$, reaction rate constant \\
\hline
\end{tabular}

$q_{0}$ and $q_{t}$ are the amount of zinc micronutrient at times zero and $t$, respectively.

Table 5. Coefficient of determination $\left(R^{2}\right)$ and standard error (SE) of kinetic models used in examining Zn fixation kinetics in the semi-arid alkaline soils of the Southern High Plains, USA.

\begin{tabular}{lr|rr|rr|rr|rr}
\hline Zinc & Depth & \multicolumn{2}{|c|}{ Zero } & \multicolumn{2}{|c|}{ First } & \multicolumn{2}{|c}{ Second } & \multicolumn{2}{c}{ Power } \\
system & $\mathrm{cm}$ & $R^{2}$ & $\mathrm{SE}$ & $R^{2}$ & $\mathrm{SE}$ & $R^{2}$ & $\mathrm{SE}$ & $R^{2}$ & $\mathrm{SE}$ \\
\hline Non-chelated & $0-15(n=3)$ & 0.67 & 0.703 & 0.73 & 0.171 & 0.77 & 0.046 & 0.92 & 0.092 \\
& $15-30(n=3)$ & 0.59 & 0.675 & 0.74 & 0.169 & 0.85 & 0.045 & 0.91 & 0.096 \\
\cline { 2 - 10 } & All $(n=6)$ & 0.66 & 0.655 & 0.76 & 0.158 & 0.83 & 0.043 & 0.95 & 0.076 \\
\hline \multirow{2}{*}{ Chelated } & $0-15(n=3)$ & 0.71 & 0.566 & 0.69 & 0.139 & 0.65 & 0.037 & 0.69 & 0.139 \\
& $15-30(n=3)$ & 0.35 & 0.808 & 0.37 & 0.216 & 0.38 & 0.061 & 0.32 & 0.224 \\
\cline { 2 - 9 } & All $(\mathrm{n}=6)$ & 0.70 & 0.489 & 0.70 & 0.118 & 0.66 & 0.030 & 0.66 & 0.120 \\
\hline
\end{tabular}

SE denotes standard error.

chelated micronutrients is not linear over the experimental period of 90 days (Fig. 1), an indication of a more complex reaction type. This finding can be related to those of Reyhanitabar et al. (2010), who reported the kinetics of DTPA extraction of zinc from calcareous soils were better described by the power-function model. The same was the case when $\mathrm{Zn}$ was examined in a single system (data not shown). Within the chelated system (Fig. 2), none of the models examined was able to reasonably describe the reduction of plantavailable $\mathrm{Zn}$ in these semi-arid soils $\left(R^{2}: 0.66\right.$ to 0.70$)$, a finding suggesting that the reduction of chelated $\mathrm{Zn}$ did not perfectly follow the speculated decay trend in these soils over the 90-day period. A literature search did not yield much information on the fixation kinetics of chelated $\mathrm{Zn}$, thus, further justifying the need for this study.

\subsection{Significance of findings to zinc management}

The fixation kinetics of non-chelated $\mathrm{Zn}$ following the power-function model over the zero-, first-, and second-order models, are an indication of a more complex reaction type. Inferences drawn from the short- and long-term experiments substantiate the need to apply $\mathrm{Zn}$ micronutrient to these semiarid soils in the chelated form as significantly less chelated $\mathrm{Zn}$ was fixed particularly within the first 14 days. Findings also highlighted the importance of timing in $\mathrm{Zn}$ micronutrient management in these soils even when chelated micronu- trient compounds are used. The simple linear relationships of change in plant-available $\mathrm{Zn}$ relative to other micronutrients $(\mathrm{Cu}, \mathrm{Mn}$, and $\mathrm{Fe})$ could be used as predictive tools. The kinetic parameters obtained from the kinetic experiments could be used for approximating how much of added $\mathrm{Zn}$ micronutrient will be available at a given time, particularly for the non-chelated $\mathrm{Zn}$ material since its fixation was reasonably described by the power-function model.

Findings from this study provide a basis for developing applications for comparing fixation pattern of $\mathrm{Zn}$ to those of other micronutrients in a given soil and also among soils. Of interest, the applications developed from this study provide a basis for a more mechanistic approach to evaluating and comparing the fixation patterns and effectiveness of different micronutrient compounds in any given soil system. A database of the reaction rate constants derived for different $\mathrm{Zn}$ micronutrient compounds could be used as a tool for making a more informed decision on $\mathrm{Zn}$ management on these semi-arid soils, an application that can be extended to soils of other regions.

\section{Conclusions}

The application of kinetic models to $\mathrm{Zn}$ fixation could be used to further the understanding of its chemistry and behavior in the soils of the semi-arid to arid climates. The reduc- 
tion of plant-available $\mathrm{Zn}$ more closely followed the powerfunction models over the zero-, first-, and second-order models in these soils, suggesting a more complex reaction type. Timing is an important practice in $\mathrm{Zn}$ management for these semi-arid soils, even when chelated compounds are used. Evidence gathered from this study suggests that kinetic model application to $\mathrm{Zn}$ fixation provides a sound basis for evaluating $\mathrm{Zn}$ dynamics among soil types and for comparing different $\mathrm{Zn}$ micronutrient compounds. The experimental setup and conditions of this study will facilitate the easier application of findings to field settings. This study provides useful background information that will enable future studies on the examination of the reaction mechanisms involved in zinc fixation in chelated and non-chelated systems of these semi-arid soils.

Acknowledgements. The authors thank the College of Agricultural Sciences and Natural Resources, Texas Tech University, for assisting with the research enhancement funds that partly supported this study.

Edited by: A. Cerdà

Reviewed by: two anonymous referees

\section{References}

Abbas, M. H. and Salem, H. M.: Kinetics of iron retention by typic torriorthent and typic haplocalcid soils supplied with some micronutrients, Ann. Agr. Sci. Mosh., 49, 301-311, 2011.

Adriano, D. C.: Trace elements in terrestrial environments: biogeochemistry, bioavailability, and risks of metals, Springer Science and Business Media, New York, 2001.

Allen, V. G., Brown, C. P., Kellison, R., Segarra, E., Wheeler, T., Dotray, P. A., Conkwright, J. C., Green, C. J., and AcostaMartinez, V.: Integrating cotton and beef production to reduce water withdrawal from the Ogallala Aquifer in the Southern High Plains, Agron. J., 97, 556-567, 2005.

Alloway, B. J. (Ed.): Micronutrient deficiencies in global crop production, Springer Science and Business Media, Netherlands, 2008.

Alloway, B. J.: Soil factors associated with zinc deficiency in crops and humans, Environ. Geochem. Hlth., 31, 537-548, 2009.

Alvarez, J. M. and Gonzalez, D.: Zinc transformations in neutral soil and zinc efficiency in maize fertilization, J. Agr. Food Chem., 54, 9488-9495, 2006.

Bindraban, P. S., Dimkpa, C., Nagarajan, L., Roy, A., and Rabbinge, R.: Revisiting fertilisers and fertilization strategies for improved nutrient uptake by plants, Biol. Fert Soils, 51, 897-911, 2015

Brevik, E. C., Cerdà, A., Mataix-Solera, J., Pereg, L., Quinton, J. N., Six, J., and Van Oost, K.: The interdisciplinary nature of SOIL, SOIL, 1, 117-129, doi:10.5194/soil-1-117-2015, 2015.

Chesworth, W. (Ed.): Encyclopedia of soil science, Springer Science and Business Media, Berlin, Germany, 2008.

Chiu, K. K., Ye, Z. H., and Wong, M. H.: Enhanced uptake of As, $\mathrm{Zn}$, and $\mathrm{Cu}$ by Vetiveria zizanioides and Zea mays using chelating agents, Chemosphere, 60, 1365-1375, 2005.
Czarnecki, S. and Düring, R.-A.: Influence of long-term mineral fertilization on metal contents and properties of soil samples taken from different locations in Hesse, Germany, SOIL, 1, 23-33, doi:10.5194/soil-1-23-2015, 2015.

Dang, Y. P., Dalal, R. C., Edwards, D. G., and Tiller, K. G.: Kinetics of zinc desorption from Vertisols, Soil Sci. Soc. Am. J., 58, 1392-1399, 1994.

Dimkpa, C. O., Latta, D. E., McLean, J. E., Britt, D. W., Boyanov, M. I., and Anderson, A. J.: Fate of $\mathrm{CuO}$ and $\mathrm{ZnO}$ nano and micro particles in the plant environment, Environ Sci. Technol., 47, 4734-4742, 2013

Eze, P. N., Udeigwe, T. K., and Stietiya, M. H.: Distribution and potential source evaluation of heavy metals in prominent soils of Accra Plains, Ghana, Geoderma, 156, 357-362, 2010.

Fageria, N. K., Baligar, V. C., and Clark, R. B.: Micronutrients in crop production, Adv. Agron., 77, 185-268, 2002.

Gee, G. W. and Bauder J. W.: Particle-size analysis, in: Methods of soil analysis, Part 1 - Pyhiscal and Mineralogical Methods, edited by: Klute, A., Soil Sci. Soc. Am., Madison, WI, 383-411, 1986.

Havlin, J. L. T., Nelson, S. L., and Beaton J. D.: Soil fertility and fertilizers: an introduction to nutrient management, 8th Edn., Pearson, Upper Saddle River, New Jersey, USA, 2013.

Kabata-Pendias, A.: Trace elements in soils and Plants, 3rd Edn., Google eBook, CRC Press, Boca Raton, Florida, USA, 2010.

Liang, J. and Karamanos, R. E.: DTPA-extractable Fe, $\mathrm{Mn}, \mathrm{Cu}$, and Zn, in: Soil Sampling and Methods of analysis, edited by: Carter, M. R., CRC Press, Boca Raton, Florida, USA, 1993.

Lindsay, W. and Norvell W. A.: Development of a DTPA soil test for zinc, iron, manganese, and copper, Soil Sci. Soc. Am. J., 42, 421-428, 1978.

Lopez-Valdivia, L. M., Fernandez, M. D., Obrador, A., and Alvarez, J. M.: Zinc transformations in acidic soil and zinc efficiency on maize by adding six organic zinc complexes, J. Agr. Food Chem., 50, 1455-1460, 2002.

Lucena, J. J., Sentís, J. A., Villén, M., Lao, T., and Pérez-Sáez, M.: IDHA chelates as a micronutrient source for green bean and tomato in fertigation and hydroponics, Agron J., 100, 813-818, 2008.

Luo, C., Shen, Z., and X. Li.: Enhanced phytoextraction of $\mathrm{Cu}, \mathrm{Pb}$, $\mathrm{Zn}$ and Cd with EDTA and EDDS, Chemosphere 59, 1-11, 2005.

Manouchehri, N., Besancon, S., and Bermond, A.: Major and trace metal extraction from soil by EDTA: equilibrium and kinetic studies, Anal. Chim. Acta, 559, 105-112, 2006.

Meers, E., Ruttens A., Hopgood, M. J., Samson, D., and Tack, F. M. G.: Comparison of EDTA and EDDS as potential soil amendments for enhanced phytoextraction of heavy metals, Chemosphere, 58, 1011-1022, 2005.

Mehlich, A.: Mehlich 3 soil test extractant: a modification of Mehlich 2 extractant, Commun. Soil Sci. Plant Anal., 15, 14091416, 1984.

Mehta, S., Fryar, A. E., and Banner, J. L.: Controls on the regionalscale salinization of the Ogallala aquifer, Southern High Plains, Texas, USA, Appl Geochem., 15, 849-864, 2000.

Nelson, D. W. and Sommers, L. E.: Total carbon, organic carbon, and organic matter, in: Methods of Soil Analysis - Part 3, Chemical Methods, edited by: Sparks, D. L., Page, A. L., Helmke, P. A., and Loeppert, R. H., Soil Sci. Soc. Am. J., Madison, Wisconsin, USA, 1996. 
Papassiopi, N., Tambouris, S., and Kontopoulos, A.: Removal of heavy metals from calcareous contaminated soils by EDTA leaching, Water Air Soil Pollut., 109, 1-15, 1999

Reyhanitabar, A. and Gilkes, R. J.: Kinetics of DTPA extraction of zinc from calcareous soils, Geoderma, 154, 289-293, 2010.

Sekhon, B. S.: Chelates for micronutrient nutrition among crops, Resonance, 8, 46-53, 2003.

Slaton, N. A., Norman, R. J., and Wilson, C. E.: Effect of zinc source and application time on zinc uptake and grain yield of flood-irrigated rice, Agron. J., 97, 272-278, 2005.

Smith, P., Cotrufo, M. F., Rumpel, C., Paustian, K., Kuikman, P. J., Elliott, J. A., McDowell, R., Griffiths, R. I., Asakawa, S., Bustamante, M., House, J. I., Sobocká, J., Harper, R., Pan, G., West, P. C., Gerber, J. S., Clark, J. M., Adhya, T., Scholes, R. J., and Scholes, M. C.: Biogeochemical cycles and biodiversity as key drivers of ecosystem services provided by soils, SOIL, 1, 665685, doi:10.5194/soil-1-665-2015, 2015.

Soil Survey Staff: Kellogg Soil Survey Laboratory Methods Manual, Soil Survey Investigations Report No. 42, Version 5.0., edited by: Burt, R. and Soil Survey Staff, US Department of Agriculture, Natural Resources Conservation Service, Lincoln, NE, USA, 2014.

Sparks, D. L.: Environmental Soil Chemistry, 2nd Edn., Academic Press, California, USA, 2003.

Sparks, D. L., Page, A. L., Helmke, P. A., Loeppert, R. H., Soltanpour, P. N., Tabatabai, M. A., Johnson, C. T., and Sumner, M. E.: Methods of soil analysis, Part 3-Chemical methods, Soil Sc. Soc. Am. Inc., Madison, WI, USA, 1996.
Stout, J. E.: Dust and environment in the southern high plains of North America, J. Arid Environ., 47, 425-441, 2001

Udeigwe, T. K., Young, J., Kandakji, T., Weindorf, D. C., Mahmoud, M. A., and Stietiya, M. H.: Elemental quantification, chemistry, and source apportionment in golf course facilities in a semi-arid urban landscape using a portable X-ray fluorescence spectrometer, Solid Earth, 6, 415-424, doi:10.5194/se-6415-2015, 2015.

Udeigwe, T. K., Eichmann, M. B., Menkiti, M. C., and Kusi, N. Y. O.: Examining the fixation kinetics of chelated and non-chelated copper and the applications to micronutrient management in semiarid alkaline soils, Solid Earth, 7, 311-321, doi:10.5194/se7-311-2016, 2016.

United States Environmental Protection Agency-Inductively Coupled Plasma (USEPA-ICP) (USEPA-ICP) Users Group: Method 200.7, available at: http://www.nmenv.state.nm.us/gwb/ documents/DairyRegs/NOIAttachment9-Exhibits/3224Exhibits/ 3224-1.pdf (last access: 30 September 2015), 1982.

World Health Organization (WHO): Guidelines on food fortification with micronutrients, available at: http://whqlibdoc.who.int/ publications/2006/9241594012_eng.pdf?ua=1\&ua=1 (last access: 30 March 2015), 2000. 